\title{
Breaking the $2 \mathrm{~V}$ barrier in Aqueous Zinc Chemistry:
}

\section{Creating $2.45 \mathrm{~V}$ and $2.8 \mathrm{~V} \mathrm{MnO}_{2}-\mathrm{Zn}$ aqueous}

\section{batteries}

Gautam G. Yadav*1, Damon Turney ${ }^{1}$, Jinchao Huang ${ }^{1}$, Xia Wei $^{l}$, Sanjoy Banerjee ${ }^{l}$

1 The CUNY Energy Institute at the City College of New York, Department of Chemical

Engineering, Steinman Hall Rm 316, 160 Convent Ave. New York, 10031, USA

AUTHOR INFORMATION

Corresponding Author

Email: ggyadav56@gmail.com

\section{AUTHOR INFORMATION}

Website: https://www.linkedin.com/in/gautam-g-y-9196a514/

Twitter: https://twitter.com/MakeMnO2great 


\section{ACKNOWLEDGMENT}

This work was supported by the U.S. Department of Energy, Office of Electricity, Energy Storage program through a contract from Sandia National Laboratories. The authors would like to thank Dr. Imre Gyuk, Manager of the DOE Energy Storage program for funding this work. Sandia National Laboratories is a multi-mission laboratory managed and operated by National Technology and Engineering Solutions of Sandia, LLC., a wholly owned subsidiary of Honeywell International, Inc., for the U.S. Department of Energy National Nuclear Security Administration under contract DE-NA-0003525. G.G.Y. would like to thank Mr. Jungsang Cho for his help.

\section{EXPERIMENTAL INFORMATION:}

Materials: Electrolytic manganese dioxide (EMD) was purchased from Tronox. Zinc (Zn) foil, manganese sulfate $\left(\mathrm{MnSO}_{4}\right)$, potassium permanganate $(\mathrm{KMnO} 4)$, potassium hydroxide $(\mathrm{KOH})$ and carbon felt were purchased from Fisher Scientific. Multiwalled carbon nanotubes (CNT) were purchased from CNano Technology Limited. Sulfuric acid $\left(\mathrm{H}_{2} \mathrm{SO}_{4}\right)$, bismuth oxide, acrylic acid (AA), potassium persulfate $\left(\mathrm{K}_{2} \mathrm{~S}_{2} \mathrm{O}_{8}\right)$ and $\mathrm{N}$,N'-methylenebisacrylamide (MBA) were purchased from Sigma-Aldrich. Nickel current collectors were purchased from Dexmet. Teflon was purchased from Dexmet. BNB90 carbon was purchased from Tronox. Cellophane was purchased from Innovia.

Electrode formulation and electrolyte: The cathode mix was made by ball milling $85 \mathrm{wt} . \%$ EMD and 15 wt. $\%$ CNT for 2 hours. A thick slurry was made by adding water to the mix. The mix was pasted onto the carbon felt and dried. The cathode loading was $\sim 6.5-10 \mathrm{mg} / \mathrm{cm}^{2}$. Zn foil was used as the anode. For the traditional alkaline $\mathrm{MnO}_{2} \mid \mathrm{Zn}$ battery, the cathode mix was made by mixing 80wt.\% EMD with 15wt.\%BNB-90 and 5wt.\% Teflon and pressing it on a Ni current collector. 
The battery was made by wrapping the $\mathrm{Zn}$ in Cellophane and pairing it with the cathode to make a traditional alkaline battery. This traditional alkaline battery was cycled against $\mathrm{Zn}$ anode between $1.75 \mathrm{~V}$ and $0.9 \mathrm{~V}$. The best alkaline battery comprised of a $\mathrm{Cu}-\mathrm{Bi}-\delta-\mathrm{MnO}_{2}$ cathode paired with $\mathrm{Zn}$ anode. This is called the best alkaline battery because it is the only cathode reported to access the $2^{\text {nd }}$ electron capacity of $\mathrm{MnO}_{2}$ in alkaline electrolyte. This cathode was made by an in-situ formation process from EMD as the starting material. The cathode mix for the best alkaline battery was made by ball milling EMD, $\mathrm{Bi}_{2} \mathrm{O}_{3}$ and $\mathrm{CNT}$ in appropriate proportions. Slurry was made by adding water and copper to the mix. The mix was pasted onto a nickel mesh, dried and pressed. The cathode composition was 55 wt.\% of EMD with the balance being covered by $\mathrm{Bi}_{2} \mathrm{O}_{3}, \mathrm{Cu}$ and CNT. The molar ratio of $\mathrm{Bi}_{2} \mathrm{O}_{3}$ to $\mathrm{MnO}$ was around 0.034 . This battery was cycled against $\mathrm{Zn}$ anode between $1.75 \mathrm{~V}$ and $0.4 \mathrm{~V}$. The birnessite $(\delta)$ phase was formed in-situ after a discharge and charge cycle.

$1 \mathrm{M}$ of $\mathrm{MnSO}_{4}$ and $0.5 \mathrm{M}$ of $\mathrm{KMnO}_{4}$ was made by dissolving the respective salts in DI water. $\mathrm{H}_{2} \mathrm{SO}_{4}$ was diluted to $0.5 \mathrm{M}$. The volumetric ratio of $\mathrm{MnSO}_{4}$ to $\mathrm{H}_{2} \mathrm{SO}_{4}$ was $4: 1$, while that of $\mathrm{KMnO}_{4}$ to $\mathrm{H}_{2} \mathrm{SO}_{4}$ was 1:3. The solutions were mixed vigorously till all the salts were dissolved and a homogenous solution was obtained.

The gelled alkaline electrolyte was made through a polymerization method. First, 100mg of MBA was mixed with $20 \mathrm{ml}$ of AA and stirred vigorously till it was completely dissolved. In the next step, around $100 \mathrm{ml}$ of $45 \mathrm{wt} . \% \mathrm{KOH}$ was chilled till $0^{\circ} \mathrm{C}$. Cooling it down to $0^{\circ} \mathrm{C}$ was important as the next step involved mixing the dissolved MBA in AA mixture with the $45 \mathrm{wt} . \% \mathrm{KOH}$, which results in an exothermic reaction. After mixing it for $10-15$ mins, around $6 \mathrm{~g}$ of $4 \mathrm{wt} . \% \mathrm{~K}_{2} \mathrm{~S}_{2} \mathrm{O}_{8}$ initiator was added to the $\mathrm{KOH}-\mathrm{AA}-\mathrm{MBA}$ mixture, which results in instant polymerization within 10-20 seconds. 
Cell Design: The electrodes were assembled into a prismatic box ( 1 in depth $\mathrm{x} 3.25$ in width $\mathrm{x} 8.5$ in height) made of polysulfone. The inner width of the polysulfone box, where the electrodes are compressed, was 0.764 in. The electrodes were compressed in the box with polypropylene shims. In the dual electrolyte high voltage aqueous batteries, two prismatic boxes were used for the cathode and anode compartments. The two boxes were connected by a hole in the center of the box. Four layers of cellophane separator was fixed between the holes of the boxes to separate the cathode and anode compartment. The two compartments were fixed together to prevent any leakage from the cathode compartment. 1 cathode and 1 anode were used for battery testing.

Cell Testing: Galvanostatic tests were carried out on a multi-channel Arbin BT 2000. Galvanostatic tests were carried out on constant current only. The cell capacity was based on the theoretical capacity of the electrode active materials and the amount present in the electrode. The C-rate of the cell was based on the theoretical capacity of the active material. In half cell tests the electrodes were controlled against the $\mathrm{Ag} / \mathrm{Ag}_{2} \mathrm{SO}_{4}$ reference electrode.

The $\mathrm{CV}$ tests were conducted on a Biologic potentiostat. For the cathode $\mathrm{CV}$, the counter electrode used was a carbon felt, while the anode CV the counter electrode used was another $\mathrm{Zn}$ foil. The working electrode for the cathode test was a $85 \mathrm{wt} . \% \mathrm{MnO}_{2}$ and $15 \mathrm{wt} . \% \mathrm{CNT}$ mix pasted on carbon felt, and for the anode was another $\mathrm{Zn}$ foil. The cathode potentials were monitored with a $\mathrm{Ag} \mid \mathrm{Ag}_{2} \mathrm{SO}_{4}$ reference. The scan rate used was $1 \mathrm{mV} / \mathrm{sec}$.

Characterization: XRD was done on a PANalytical X'Pert Pro Powder Diffraction instrument fitted with a PIXcel ${ }^{1 \mathrm{D}}$ fast detector and $\mathrm{Cu}-\mathrm{K} \alpha$ filter. SEM images were taken on a Zeiss Supra 55 VP field emission microscopy. SEM images were also taken on Helios NanoLab 660SEM with EDX capabilities. 


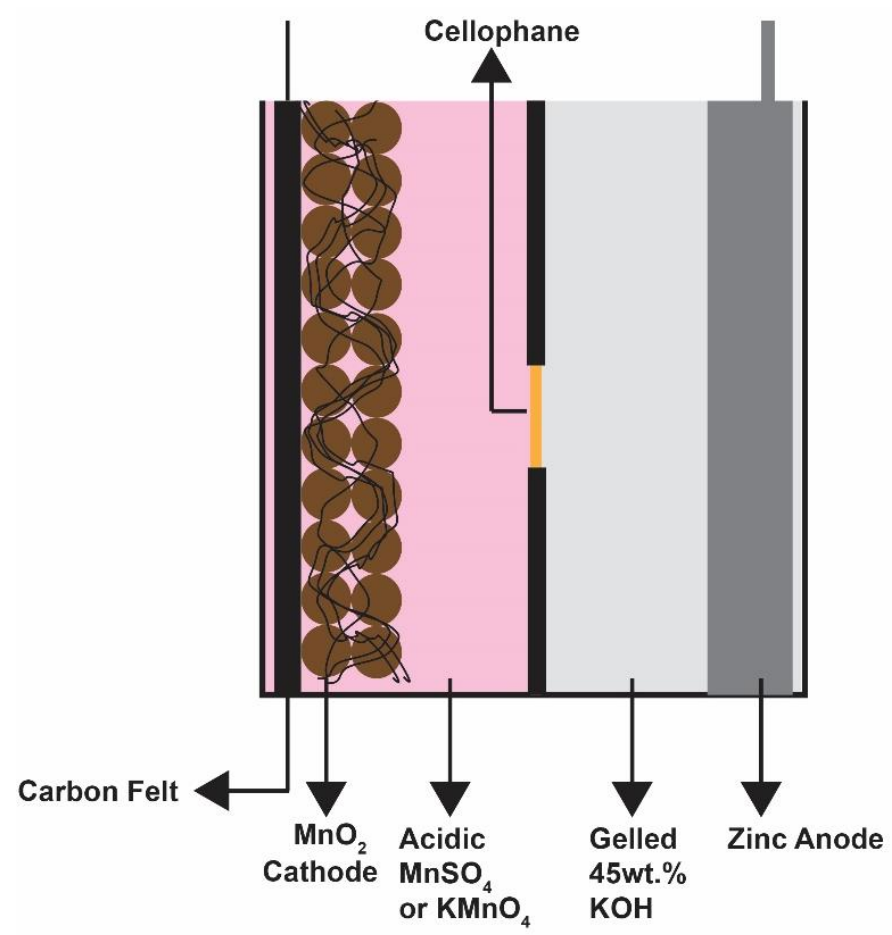

Figure S1. Schematic drawing of the experimental setup.

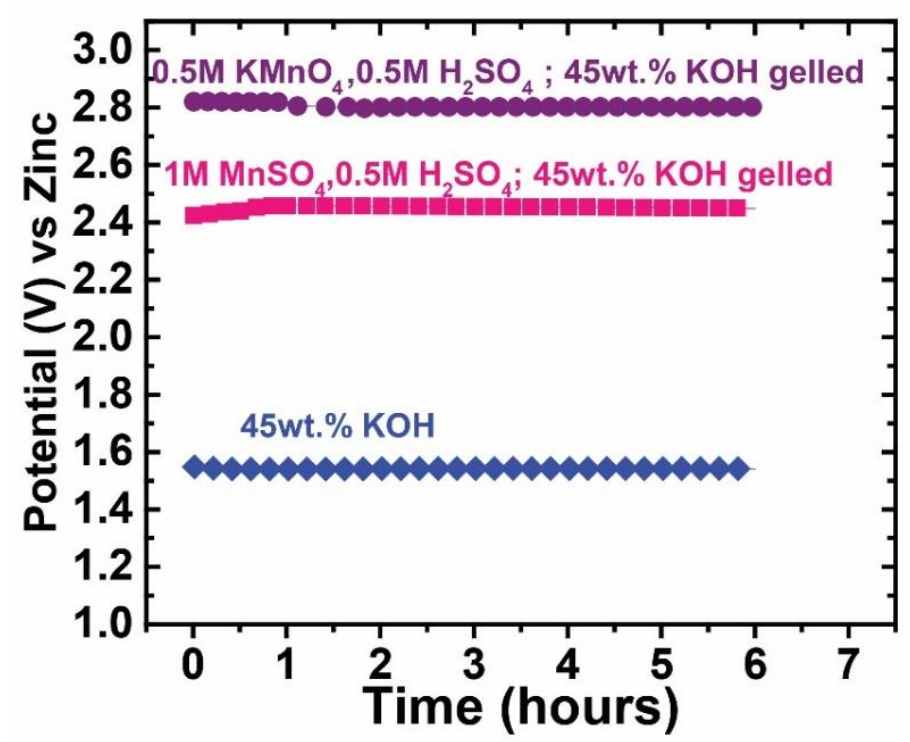

Figure S2. Open circuit potential of $\mathrm{MnO}_{2} \mid \mathrm{Zn}$ batteries containing acidic $\mathrm{MnSO}_{4}$ and $\mathrm{KMnO}_{4}$ in the cathode compartment and $45 \mathrm{wt} . \%$ gelled $\mathrm{KOH}$ in the anode compartment, and a traditional alkaline $\mathrm{MnO}_{2} \mid \mathrm{Zn}$ battery. 
a

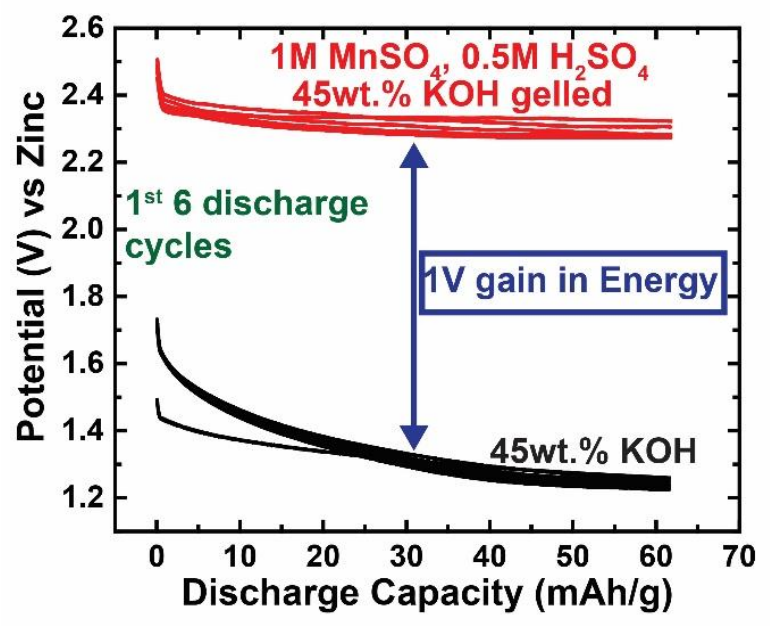

b

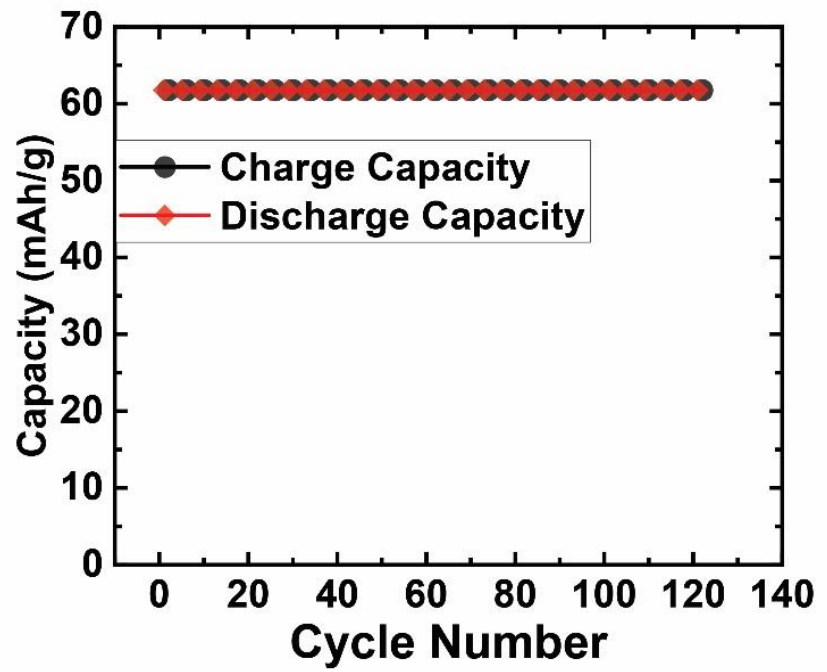

Figure S3. (a) Comparison of discharge curves between a high voltage aqueous $\mathrm{MnO}_{2} \mid \mathrm{Zn}$ battery containing acidic $\mathrm{MnSO}_{4}$ and $45 \mathrm{wt} . \%$ gelled $\mathrm{KOH}$ and a traditional alkaline $\mathrm{MnO}_{2} \mid \mathrm{Zn}$ battery.

(b) Capacity retention on cycling of a high voltage aqueous $\mathrm{MnO}_{2} \mid \mathrm{Zn}$ battery containing acidic $\mathrm{MnSO}_{4}$ and $45 \mathrm{wt} . \%$ gelled $\mathrm{KOH}$.

a

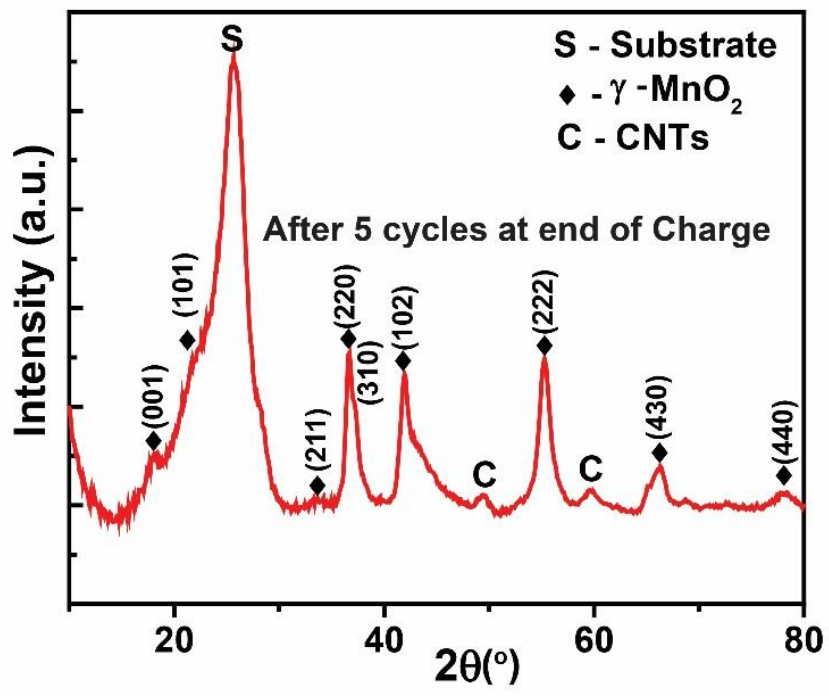

b

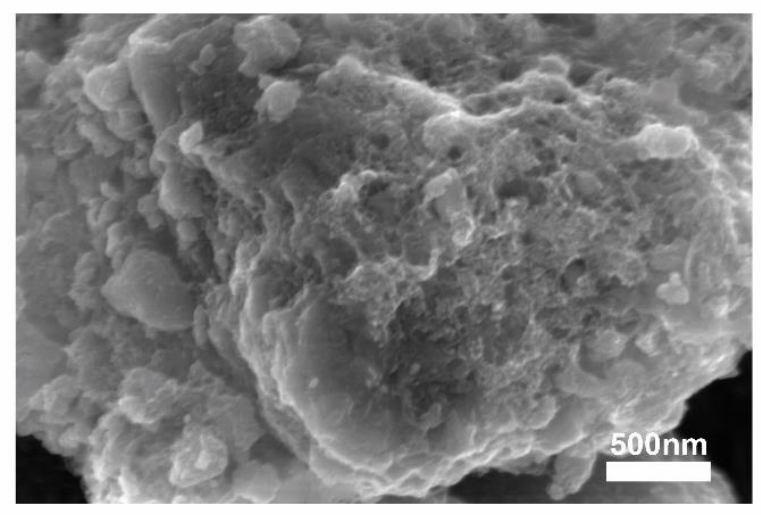

Figure S4. (a) XRD of a cycled cathode on charge in an acidic $\mathrm{MnSO}_{4}$ electrolyte. (b) SEM of a cycled cathode on charge, where $\mathrm{MnO}_{2}$ deposition is seen on carbon. 


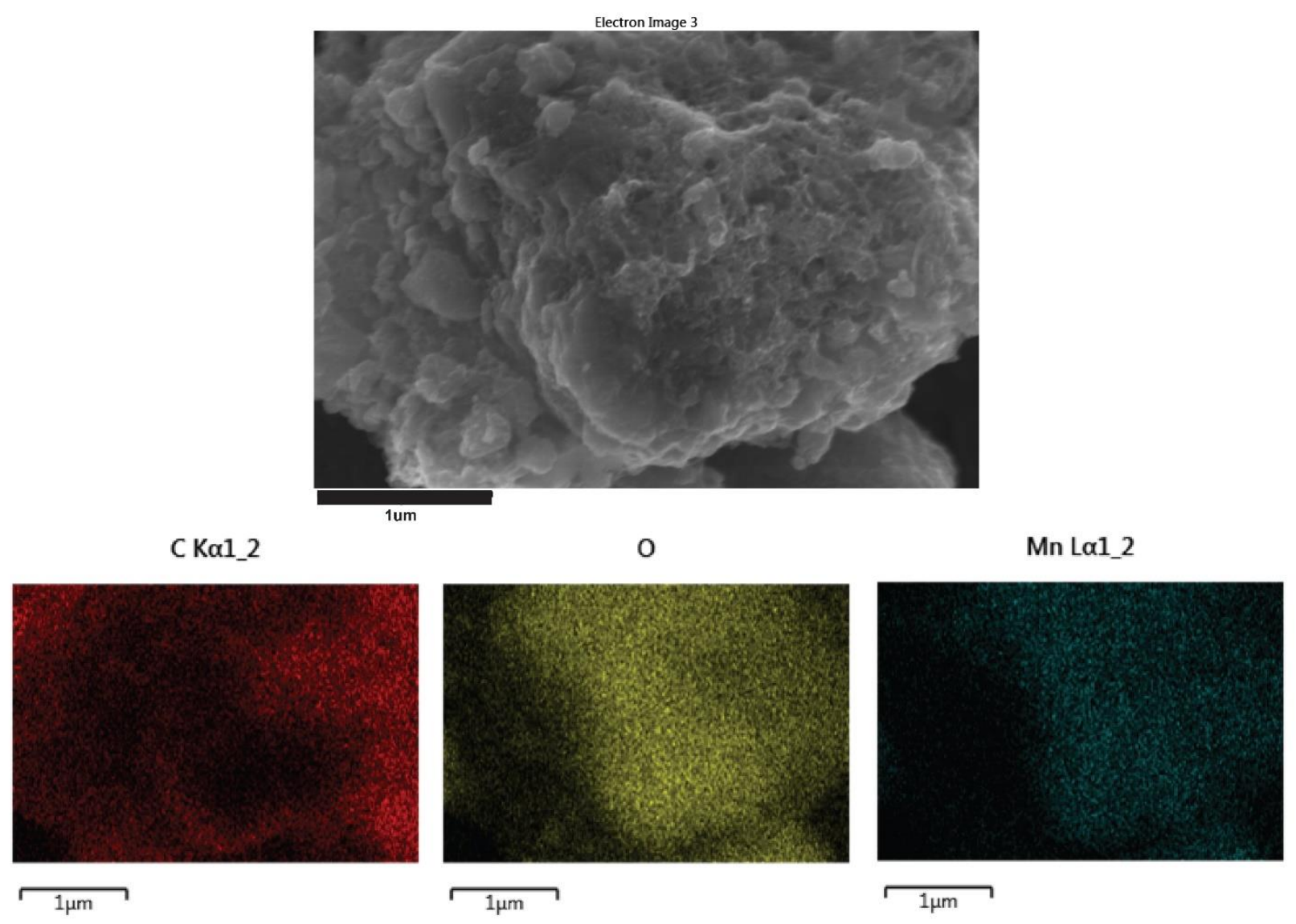

Figure S5. EDX of a cycled cathode stopped on charge in a $\mathrm{MnO}_{2} \mid \mathrm{Zn}$ battery with acidic $\mathrm{MnSO}_{4}$ in the cathode compartment and $45 \mathrm{wt} . \%$ gelled $\mathrm{KOH}$. The atomic ratio of Mn:O is 1:2. 

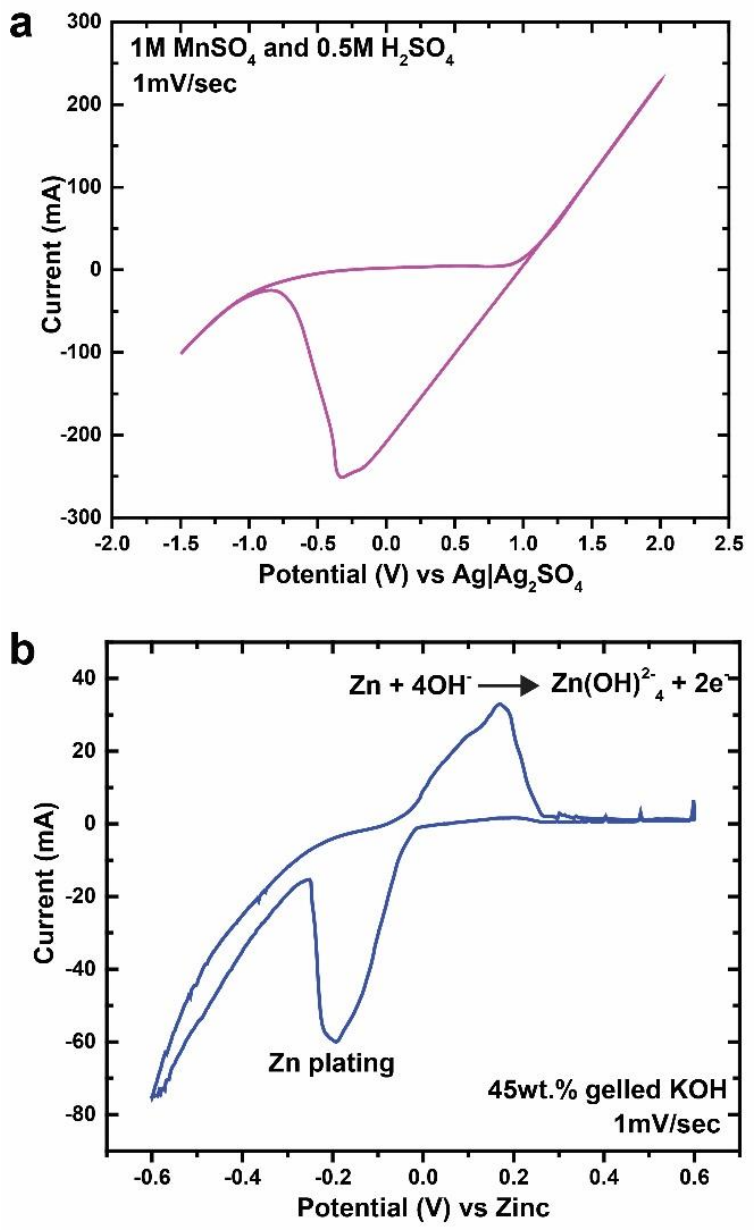

Figure S6. (a) CV curve of a $\mathrm{MnO}_{2}$ cathode in acidic $\mathrm{MnSO}_{4}$ electrolyte. (b) $\mathrm{CV}$ curve of a $\mathrm{Zn}$ anode in $45 \mathrm{wt} . \%$ gelled $\mathrm{KOH}$ electrolyte. 


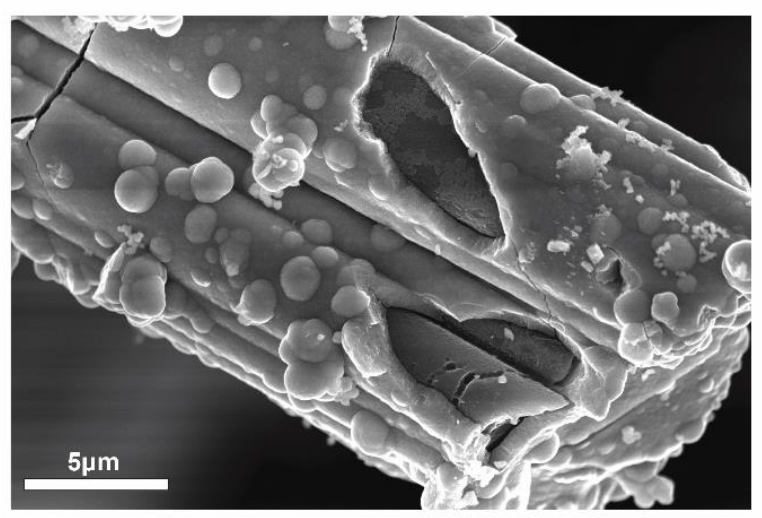

Figure S7. SEM of a charged cathode from a $\mathrm{MnO}_{2} \mid \mathrm{Zn}$ battery containing acidic $\mathrm{KMnO}_{4}$ and 45wt.\% gelled $\mathrm{KOH}$ 

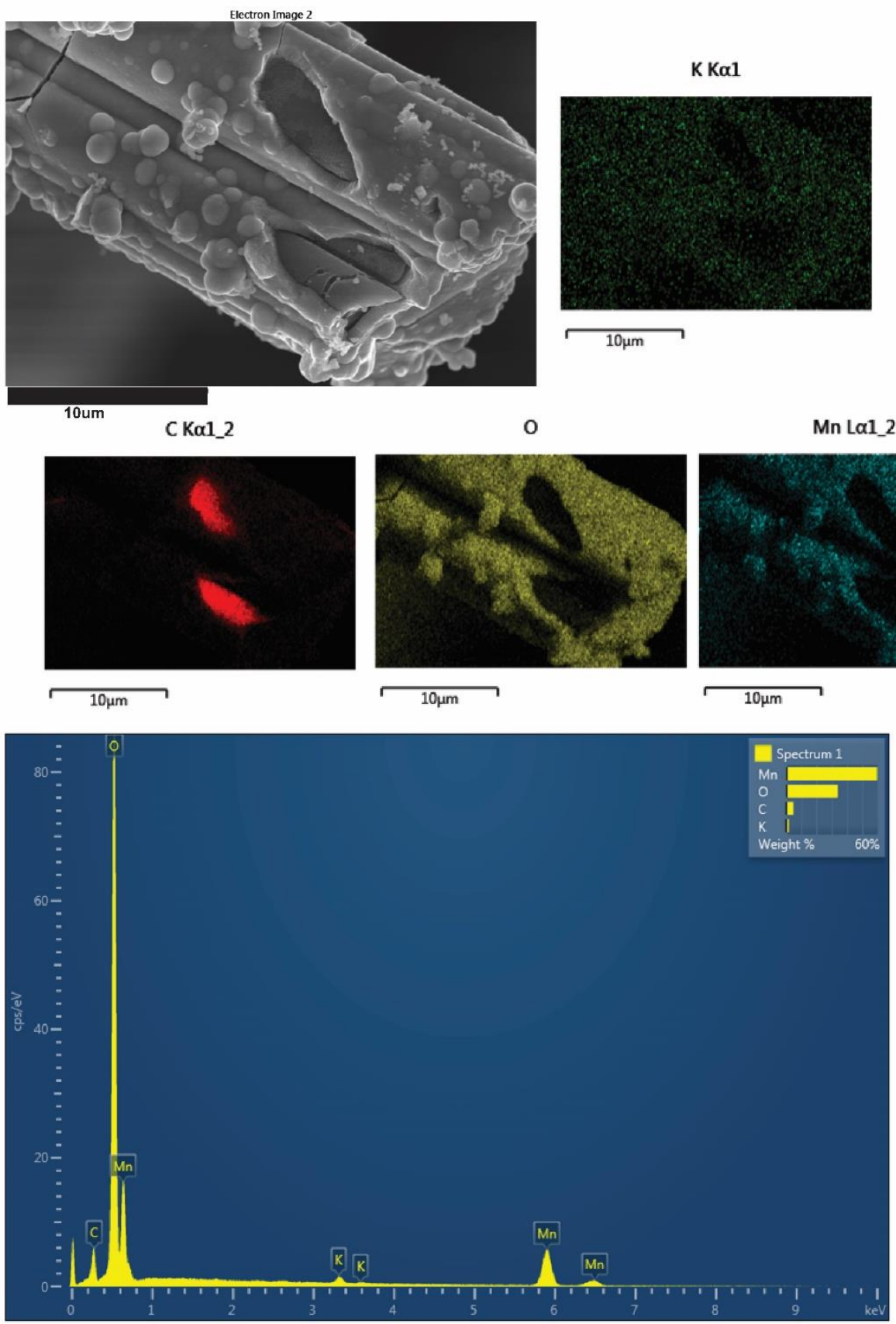

Figure S8. EDX of a cycled cathode stopped on charge in a $\mathrm{MnO}_{2} \mid \mathrm{Zn}$ battery with acidic $\mathrm{KMnO}_{4}$ in the cathode compartment and $45 \mathrm{wt} . \%$ gelled $\mathrm{KOH}$. The atomic ratio of $\mathrm{K}: \mathrm{Mn}: \mathrm{O}$ is 0.039:1:1.944. 


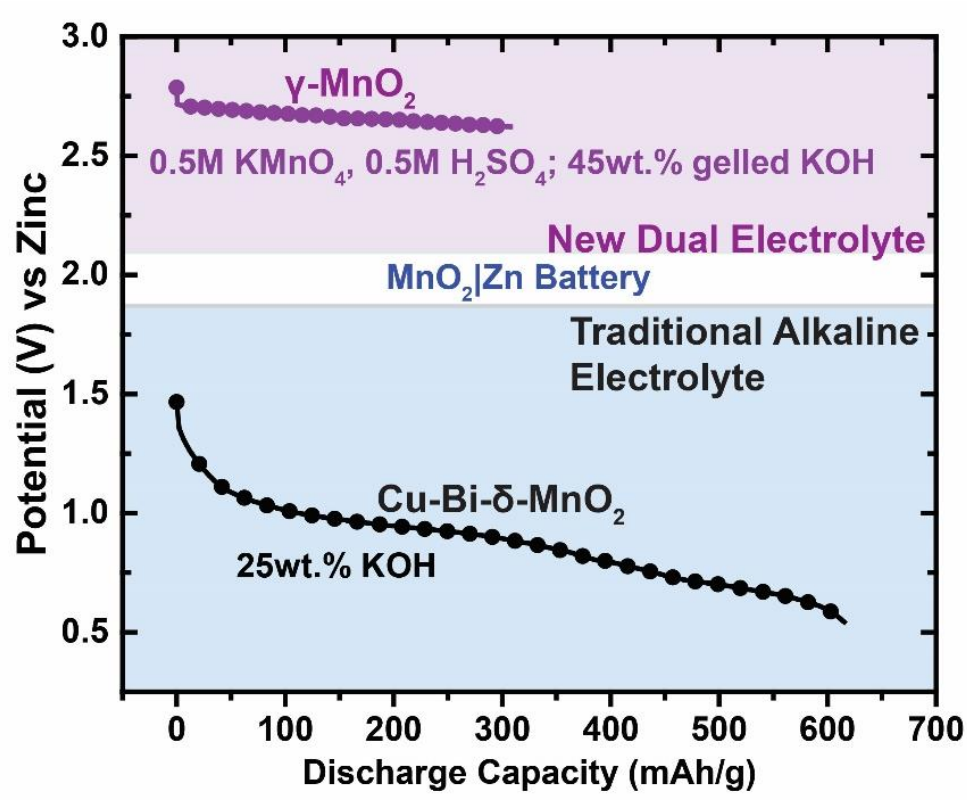

Figure S9. Comparison of cycling curves of a $\mathrm{MnO}_{2} \mid \mathrm{Zn}$ battery with acidic $\mathrm{KMnO}_{4}$ in the cathode compartment and $45 \mathrm{wt} . \%$ gelled $\mathrm{KOH}$, and a $\mathrm{Cu}^{2+}$ intercalated Bi-birnessite| $\mathrm{Zn}$ battery in traditional $25 \mathrm{wt} . \% \mathrm{KOH}$ at $\mathrm{C} / 20$. The drawback of the traditional alkaline battery has been its low voltage although it is capable of accessing its theoretical two electron capacity.

\section{Supplementary Note:}

Aqueous $\mathrm{MnO}_{2} \mid \mathrm{Zn}$ batteries in both acidic and alkaline electrolytes have been used for over a century ${ }^{1}$. Alkaline batteries are widespread commercially because of their superior energy density and power characteristics ${ }^{1}$. They are limited to primary batteries because of the poor rechargeability characteristics of its active raw materials $-\mathrm{MnO}_{2}$ and $\mathrm{Zn}$. However, recently acidic batteries have been gaining traction because of reports of better rechargeability ${ }^{2}$. Both of these systems are hindered by low voltage, which places them at a disadvantaged compared to high voltage $\mathrm{Li}$-ion batteries. If high voltages in $\mathrm{Zn}$-anode batteries could be coupled with $100 \%$ utilization of the theoretical capacity of $\mathrm{MnO}_{2}(308 \mathrm{mAh} / \mathrm{g}$ based on one electron reaction) then it 
would be the forerunner as the best possible battery chemistry to compete or even replace $\mathrm{Li}$-ion batteries.

In this express communication, we have achieved the necessary high voltage in an aqueous battery by coupling a $\mathrm{MnO}_{2}$ cathode in acidic electrolyte and a $\mathrm{Zn}$ anode in gelled alkaline electrolyte. By taking advantage of the widely different redox potentials achievable in the acid vs base electrolytes, we were able to cross the $2 \mathrm{~V}$ barrier in aqueous batteries. More importantly, by gelling the anode electrolyte, we were able to prevent the mixing of the two electrolytes and were able to hold a stable operating potential. When pairing two different electrolytes, expensive specialized membranes have been used, for example NASICON, LISICON and ion-exchange membranes. In our case, we were able to use the cheapest, most readily available cellulosic separator - cellophane. The $\mathrm{MnO}_{2}$ in acidic electrolyte was able to access its theoretical one electron capacity of $308 \mathrm{mAh} / \mathrm{g}$ reversibly. Overall this design creates a battery capable of competing with $\mathrm{Li}$-ion batteries in terms of energy density, cost and safety as demonstrated in Figure SN1.

In this supplementary note, our goal is to review the current status quo of alkaline batteries in order to put our new development into perspective. We focus on alkaline $\mathrm{MnO}_{2} \mid \mathrm{Zn}$ batteries because it is the only version that is commercially available on a large scale for the primary battery market, and a rechargeable version in some niche markets. 


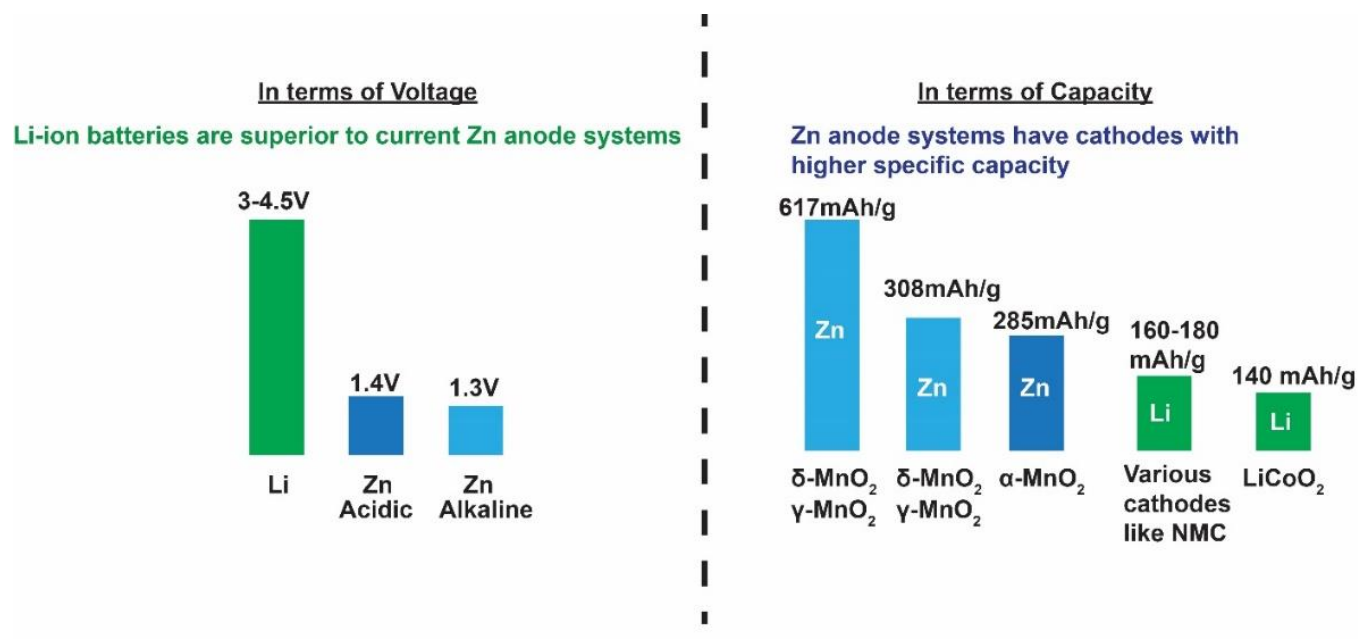

NEW HIGH VOLTAGE AQUEOUS BATTERIES

With the newly designed dual electrolyte batteries aqueous $\mathrm{Zn}$ batteries can compete

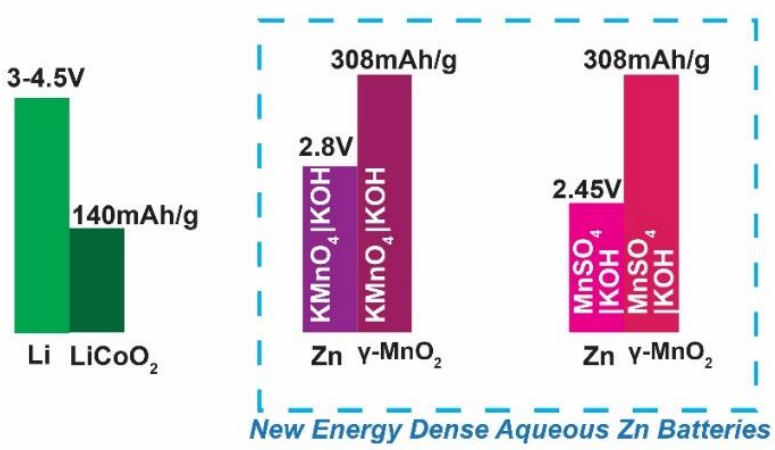

Figure SN1. Summary and schematic explanation of the advantageous battery characteristics of the newly designed high voltage aqueous $\mathrm{MnO}_{2} \mid \mathrm{Zn}$ battery compared to $\mathrm{Li}$-ion.

\section{Mechanism of $\mathrm{MnO}_{2}$ and $\mathrm{Zn}$ reactions in Alkaline Batteries:}

$\mathrm{MnO}_{2}$ in alkaline batteries is the electrolytic manganese dioxide (EMD)-type, where it is commonly indexed or written as $\gamma-\mathrm{MnO}_{2}$. EMD in alkaline electrolyte delivers its theoretical two electron capacity in two steps: 


$$
\begin{aligned}
& \mathrm{MnO}_{2}+\mathrm{H}_{2} \mathrm{O}+1 \mathrm{e}^{-} \longrightarrow \mathrm{MnOOH}+\mathrm{OH}^{-} \ldots \ldots \ldots \ldots \ldots 1^{\text {st }} \text { electron reaction }(308 \mathrm{mAh} / \mathrm{g}) \\
& \mathrm{MnOOH}+\mathrm{H}_{2} \mathrm{O}+1 \mathrm{e}^{-} \longrightarrow \mathrm{Mn}(\mathrm{OH})_{2}+\mathrm{OH}^{-} \ldots \ldots \ldots \ldots \ldots 2^{\text {nd }} \text { electron reaction }(308 \mathrm{mAh} / \mathrm{g})
\end{aligned}
$$

The $1^{\text {st }}$ electron reaction is a solid state reaction, where proton inserts into the tunneled structure of the EMD cathode. This proton insertion homogenous reaction is seen as a sigmoidal shaped curve in the potential-capacity plot as shown in Figure SN2. The $2^{\text {nd }}$ electron reaction is a dissolution-precipitation reaction, where the $\mathrm{Mn}^{3+}$ from $\mathrm{MnOOH}$ dissolve into the alkaline electrolyte, reduce and precipitate out as $\mathrm{Mn}(\mathrm{OH})_{2} \cdot{ }^{3-6}$ This heterogeneous two-phase reaction is seen as a flat curve in Figure SN2.

The $\mathrm{Zn}$ anode in alkaline electrolyte delivers its two electron capacity $(820 \mathrm{mAh} / \mathrm{g})$ through a dissolution-precipitation reaction ${ }^{7}$.

$\mathrm{Zn}+4 \mathrm{OH}^{-} \rightarrow \mathrm{Zn}(\mathrm{OH})_{4}{ }^{2-}+2 \mathrm{e}^{-}$

$\mathrm{Zn}(\mathrm{OH})_{4}^{2-} \rightarrow \mathrm{ZnO}+2 \mathrm{OH}^{-}+\mathrm{H}_{2} \mathrm{O}$

The $\mathrm{Zn}$ anode reaction and capacity utilization is dependent on electrolyte concentration. Zn's dissolution is paramount to extract the maximum capacity from the electrode. Generally, at 45wt.\% $\mathrm{KOH} \mathrm{Zn}$ dissolves the most, so it is able to deliver most of its theoretical capacity. At lower concentrations of $<25 \mathrm{w} / \mathrm{w} \% \mathrm{KOH}, \mathrm{Zn}$ is known to passivate, however at too high $\mathrm{KOH}$ concentration the conductivity decreases. Figure SN3 shows the important properties as a function of $\mathrm{KOH}$ concentration. 


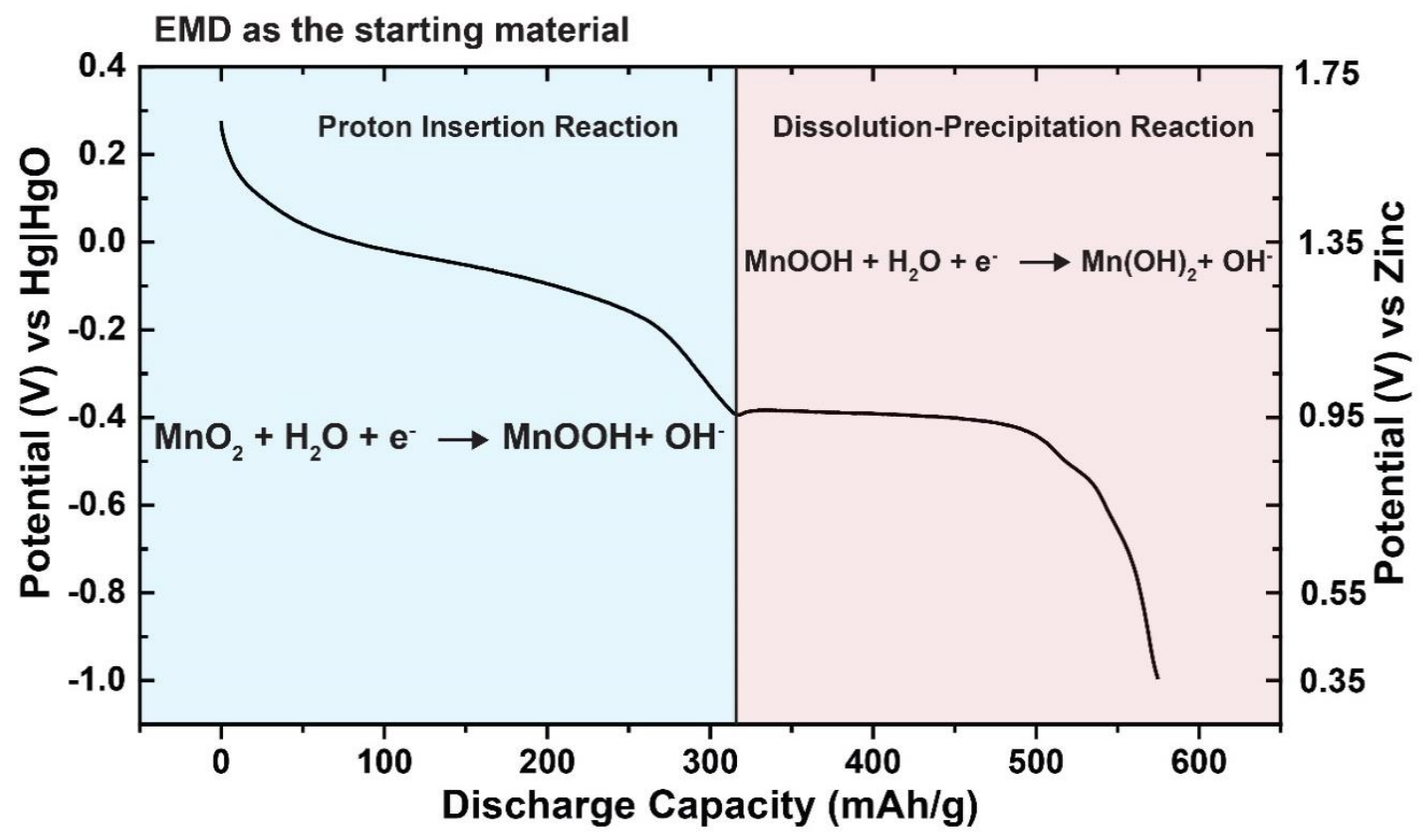

Figure SN2. Potential versus discharge capacity for a $\mathrm{MnO}_{2}$ cathode in $25 \mathrm{wt} . \% \mathrm{KOH}$ electrolyte. The counter electrode in this experiment was sintered nickel and the potential was monitored with a mercury $(\mathrm{Hg}) \mid$ mercury $(\mathrm{HgO})$ reference electrode. The potential against $\mathrm{Zn}$ is shown on the right axis. When a $\mathrm{Zn}$ anode is used the $2^{\text {nd }}$ electron reaction gets affected and the flat potential is lost.

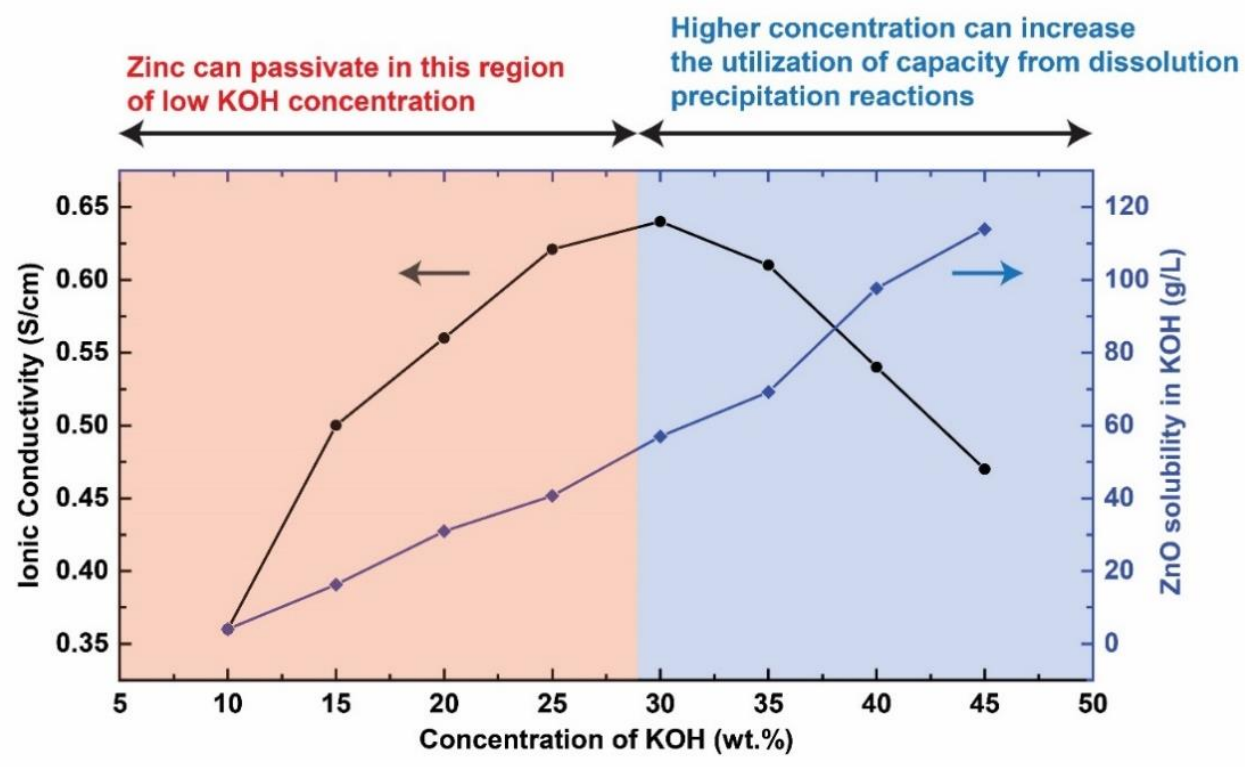


Figure SN3. Ionic conductivity and $\mathrm{Zn}$ solubility versus $\mathrm{KOH}$ concentration.

\section{Primary Alkaline Batteries:}

Primary $\mathrm{MnO}_{2} \mid \mathrm{Zn}$ batteries currently available in the market use EMD as the cathode active material because its discharge curve gives higher voltage and energy compared to other polymorphs of $\mathrm{MnO}_{2}$. These primary batteries are capable of delivering only the $1^{\text {st }}$ electron reaction of $\mathrm{MnO} 2 \backslash$, as shown in Figure $\mathrm{SN} 4$. The $2^{\text {nd }}$ electron reaction of $\mathrm{MnO} 2$ is not seen in these batteries because dissolved $\mathrm{Zn}$ ions are known to poison the $\mathrm{MnO}_{2}$ cathode and terminate the $2^{\text {nd }}$ electron reaction. This results in a loss of energy density. Nevertheless, primary $\mathrm{MnO}_{2} \mid \mathrm{Zn}$ batteries dominate the primary battery market because of its low cost and safe raw materials. However, its position is being challenged by primary $\mathrm{MnO}_{2} \mid \mathrm{Li}$ batteries, which also deliver $308 \mathrm{mAh} / \mathrm{g}$ but at a higher voltage between 2-3V. But these $\mathrm{MnO}_{2} \mid \mathrm{Li}$ batteries are only available in small formats because of its cost and flammable characteristics. There is a great incentive to develop high voltage aqueous batteries to keep $\mathrm{MnO}_{2} \mid \mathrm{Zn}$ 's position as the dominant chemistry for the primary market. 


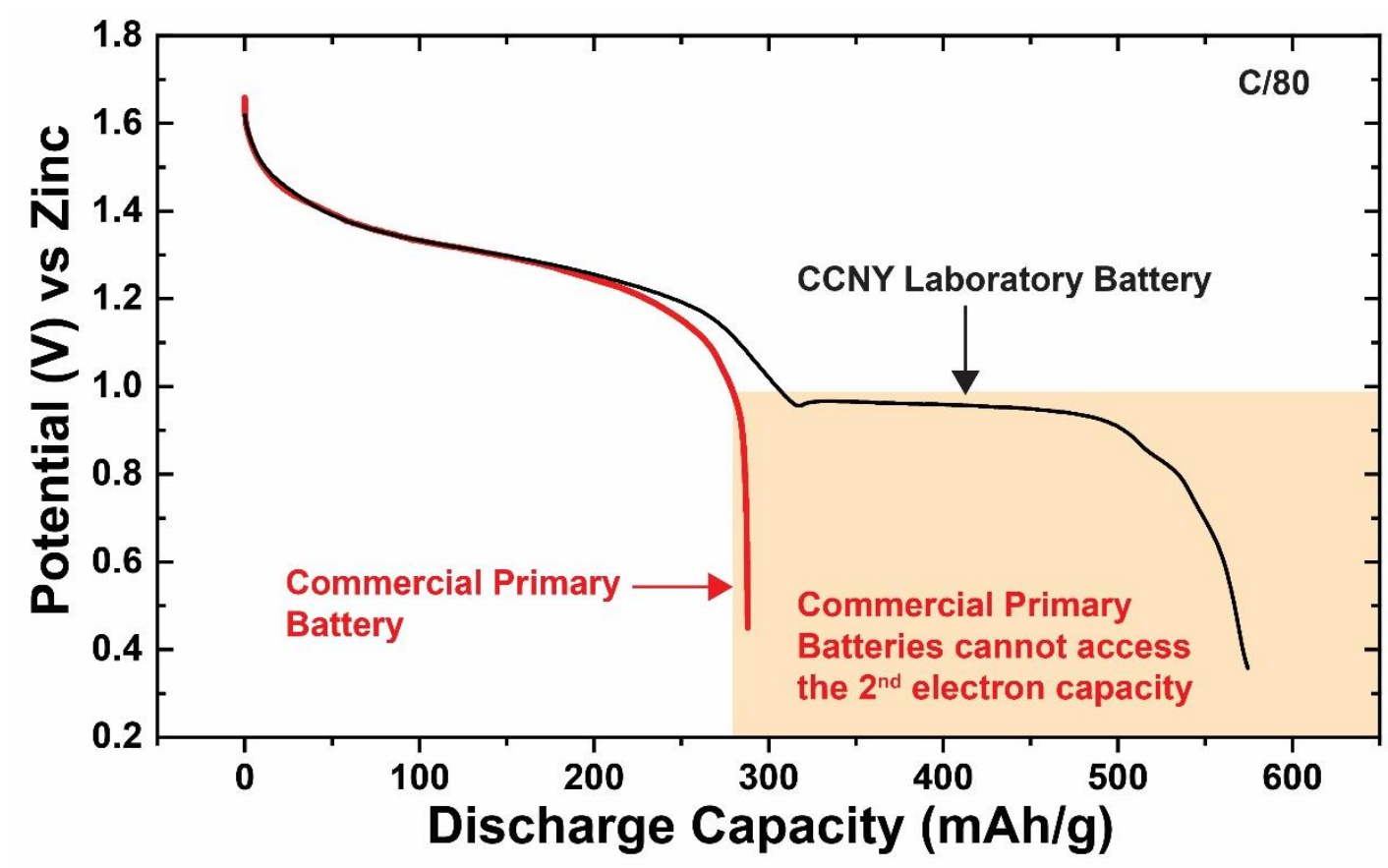

Figure SN4. Potential versus discharge capacity for a commercial primary $\mathrm{MnO}_{2} \mid \mathrm{Zn}$ battery (red curve). The CCNY laboratory battery potential is corrected for a $\mathrm{Zn}$ anode.

\section{Rechargeable Alkaline Batteries:}

Currently available rechargeable $\mathrm{MnO}_{2} \mid \mathrm{Zn}$ batteries are commonly called rechargeable alkaline manganese dioxide (RAM). They also use EMD as the cathode active material. The drawback of RAM batteries is their limitation to low DOD of the cathode, which creates low energy density. The EMD material is not rechargeable with its full $2^{\text {nd }}$ electron capacity. Figure SN5 shows that when a EMD cathode is cycled at $100 \%$ DOD, it loses almost all of its capacity. There are a number of reasons for this loss in capacity ${ }^{8}$ :

1] Breakdown of crystal structure because of volume expansion

2] Formation of inactive hausmannite $\left(\mathrm{Mn}_{3} \mathrm{O}_{4}\right)$ and hetaerolite $\left(\mathrm{ZnMn}_{2} \mathrm{O}_{4}\right)$ 
3] Zinc poisoning to form $\mathrm{ZnMn2O4}$

4] Loss of Mn ions because of the dissolution of $\mathrm{Mn}^{3+}$.

The EMD cathode is difficult to cycle in the $2^{\text {nd }}$ electron dissolution-precipitation regime. Therefore, to make the cathode rechargeable a concept of limited DOD cycling was developed ${ }^{9}$, where the EMD is cycled between $10-40 \%$ of its $1^{\text {st }}$ electron intercalation capacity. The concept of limited DOD cycling is shown in Figure SN6a and b, where it can been that the RAM battery is very stable at $20 \%$ DOD of the $1^{\text {st }}$ electron capacity. Although this method considerably improves cycle life, it brings down the energy density of the battery considerably as the voltage and capacity are severely curtailed.

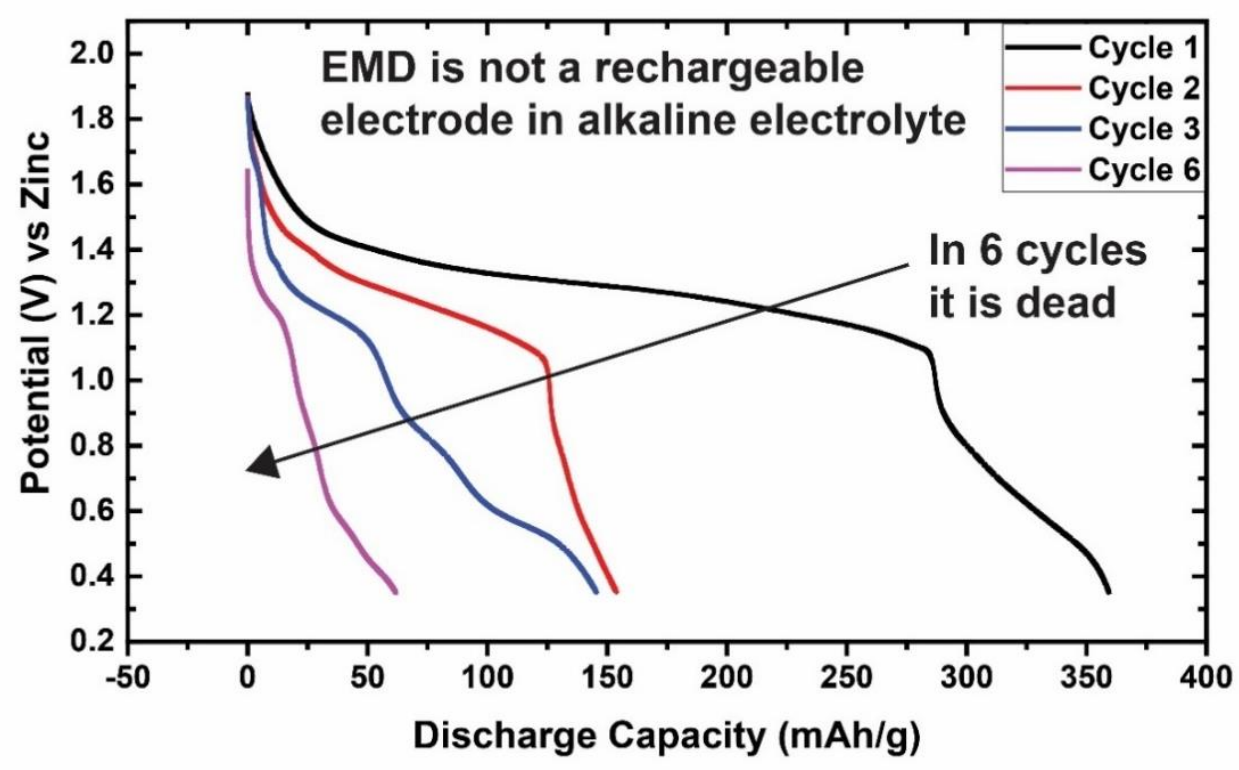


Figure SN5. Cycling of a $\mathrm{MnO}_{2} \mid \mathrm{Zn}$ battery in $45 \mathrm{wt} . \% \mathrm{KOH}$ at $100 \%$ utilization or depth-ofdischarge (DOD) of its two electron capacity $(\sim 617 \mathrm{mAh} / \mathrm{g})$. The cathode is not able to cycle at $100 \%$ DOD and within 6 cycles it loses almost all of its capacity.
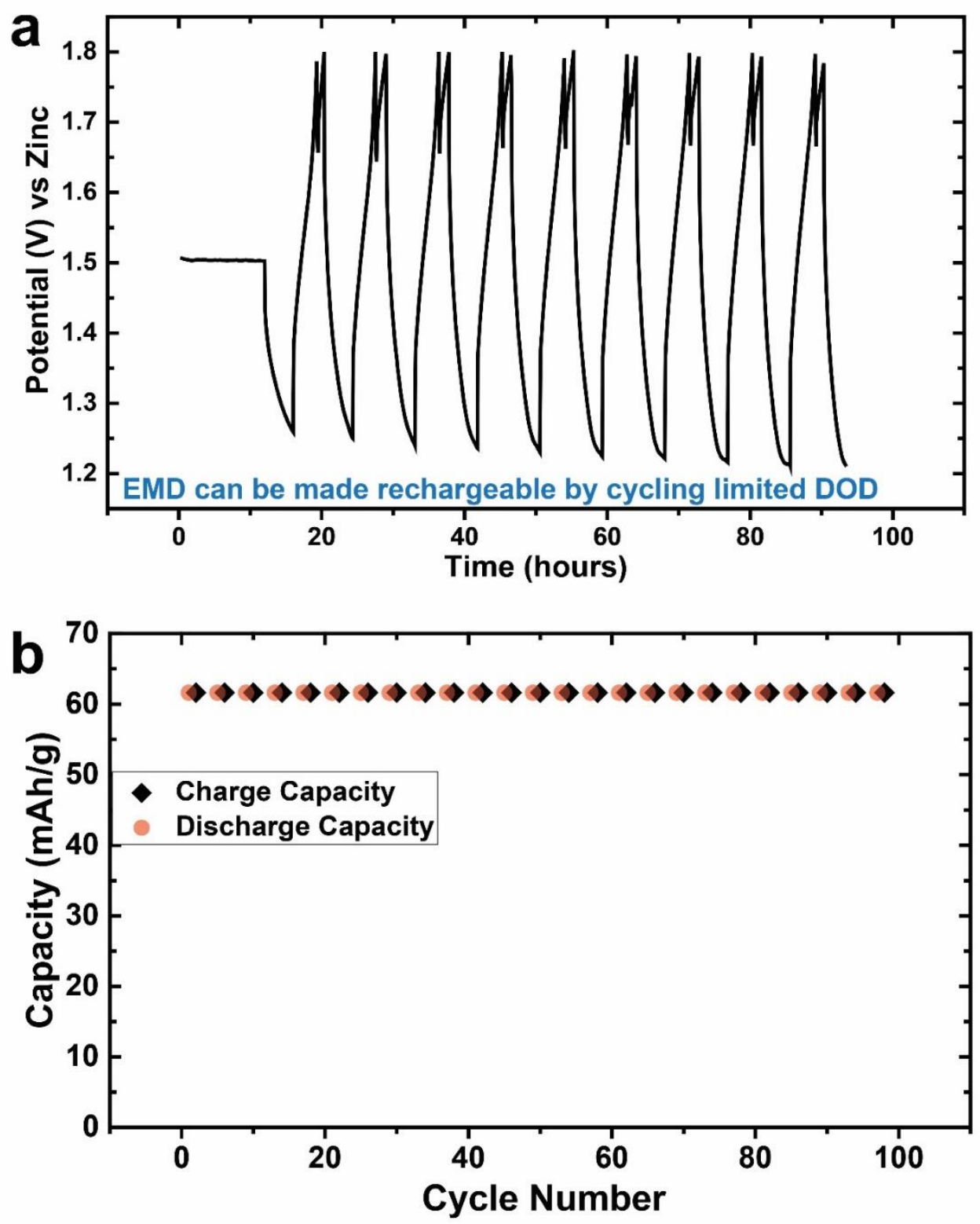
Figure SN6. (a) Cycling of a $\mathrm{MnO}_{2} \mid \mathrm{Zn}$ battery in $45 \mathrm{wt} . \% \mathrm{KOH}$ at $20 \%$ utilization or depth-ofdischarge (DOD) of its one electron capacity $\left(308 \mathrm{mAh} / \mathrm{g}\right.$ ). (b) Capacity retention of a $\mathrm{MnO}_{2} \mid \mathrm{Zn}$ battery in $45 \mathrm{wt} . \% \mathrm{KOH}$ at $20 \%$ utilization or depth-of-discharge (DOD) of its one electron capacity $(308 \mathrm{mAh} / \mathrm{g})$.

Recently, a breakthrough in rechargeable alkaline batteries was reported ${ }^{5-7}$, where the authors were able to cycle $100 \%$ DOD of the $2^{\text {nd }}$ electron capacity for over 1000 cycles. They were able to do this by creating the layered phase of $\mathrm{MnO}_{2}\left(\delta-\mathrm{MnO}_{2}\right.$, birnessite) intercalated with $\mathrm{Cu}$ and $\mathrm{Bi}$ ions. The birnessite-phase of $\mathrm{MnO}_{2}$ is able to discharge the $2^{\text {nd }}$ electron capacity much more efficiently than EMD because of its advantageous layered characteristics (see Figure SN7) The $\mathrm{Cu}$ and $\mathrm{Bi}$ ions were used for reducing charge transfer resistance and complexing with the dissolved $\mathrm{Mn}$ ions to prevent hausmannite $\left(\mathrm{Mn}_{3} \mathrm{O}_{4}\right)$ and hetaerolite $\left(\mathrm{ZnMn}_{2} \mathrm{O}_{4}\right)$ formation. This was a significant advancement in rechargeable alkaline batteries. However, the drawback of even this battery is the low voltage of $\sim 1 \mathrm{~V}$. Although in terms of capacity the energy density is significantly improved, voltage is considered to be a paramount for most applications, where Li-ion batteries has succeded. 


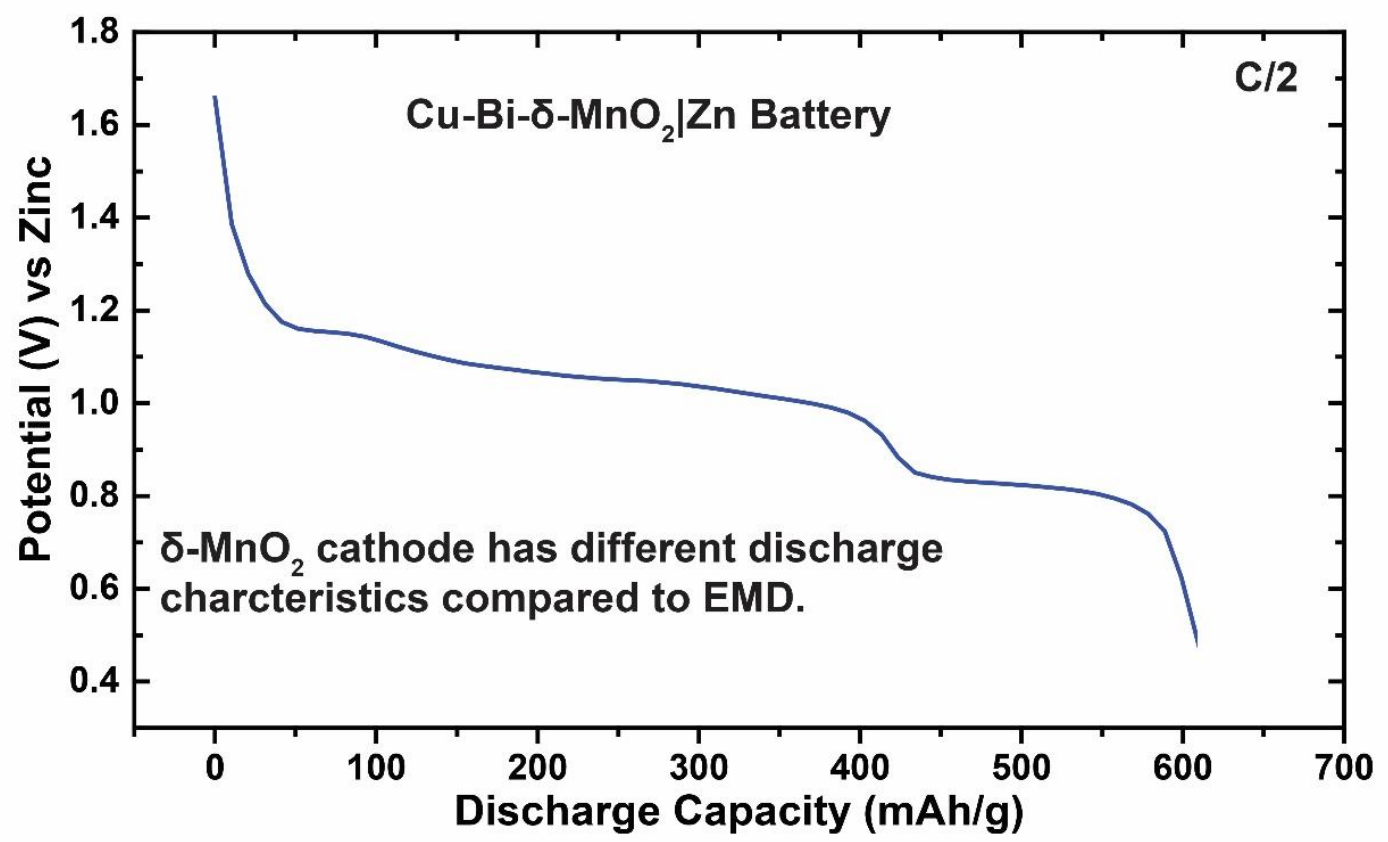

Figure SN7. Discharge curve of a $\mathrm{Cu}-\mathrm{Bi}-\delta-\mathrm{MnO}_{2} \mid \mathrm{Zn}$ battery.

\section{Separator Cost:}

The new high-voltage battery developed here will greatly reduce the cost of Mn-Zn energy storage because higher voltage means more energy stored, and only low-cost cellophane, manganese, and zinc are used for composition. Past methods have relied on using LISICON and special ion selective membranes for separating electrolytes of different $\mathrm{pHs}$ or types. These are very expensive to make. The cost of some of these specialized membranes can go beyond $\$ 700-1000 / \mathrm{kg}$, while the cost of cellophane can range from $\$ 3-4 / \mathrm{kg}$. Rigorous technoeconomic analyses are required to get the exact number; however, from a general point of view it can be seen that cellophane is the cheapest available separator. It is used on a large scale for a wide range of applications. The use of cellophane in this battery is a game changer as the cost remains low in the range of primary 
alkaline batteries, but the added benefit is the rechargeability to $308 \mathrm{mAh} / \mathrm{g}$ over $2 \mathrm{~V}$ operating range.

References:

1. Chabre YP. Step Potential Electrochemical Spectroscopy of Proton Intercalation in $\gamma /$ MnO[sub 2]. J Electrochem Soc. 2006;138(1):329. doi:10.1149/1.2085568

2. Pan H, Shao Y, Yan P, et al. Reversible aqueous zinc/manganese oxide energy storage from conversion reactions. Nat Energy. 2016;1(October 2017):16039-16045. doi:10.1038/nenergy.2016.39

3. Kozawa A, Yeager JF. Cathodic Reduction Mechanism of $\mathrm{MnOOH}$ to $\mathrm{Mn}(\mathrm{OH})[\mathrm{sub} 2]$ in Alkaline Electrolyte. J Electrochem Soc. 2007;115(10):1003. doi:10.1149/1.2410843

4. Kozawa A, Kalnoki-Kis T, Yeager JF. Solubilities of $\mathrm{Mn}(\mathrm{II})$ and $\mathrm{Mn}(\mathrm{III})$ Ions in Concentrated Alkaline Solutions. $J$ Electrochem Soc. 2007;113(5):405. doi: $10.1149 / 1.2423984$

5. Yadav GG, Gallaway JW, Turney DE, et al. Regenerable Cu-intercalated MnO 2 layered cathode for highly cyclable energy dense batteries. Nat Commun. 2017;8(May 2016):1-9. doi:10.1038/ncomms 14424

6. Yadav GG, Wei X, Huang J, Turney D, Nyce M, Banerjee S. Accessing the second electron 
capacity of $\mathrm{MnO} 2$ by exploring complexation and intercalation reactions in energy dense alkaline batteries. Int $J$ Hydrogen Energy. 2018;43(17):8480-8487. doi:10.1016/j.ijhydene.2018.03.061

7. Yadav GG, Wei X, Huang J, et al. A conversion-based highly energy dense $\mathrm{Cu} 2+$ intercalated Bi-birnessite/Zn alkaline battery. J. Mater. Chem. A. 2017, 5: 15845:15854. doi:10.1039/c7ta05347a

8. Huang J, Yadav GG, Gallaway JW, Wei X, Nyce M, Banerjee S. A calcium hydroxide interlayer as a selective separator for rechargeable alkaline $\mathrm{Zn} / \mathrm{MnO} 2$ batteries. Electrochem commun. 2017;81:136-140. doi:10.1016/j.elecom.2017.06.020

9. Kordesch K, July F. United States Patent Office. J Am Soc Nav Eng. 2009;39(4):620-622. doi:10.1111/j.1559-3584.1927.tb04229.x 